\title{
Perilaku Mencatat dan Kemampuan Memori pada Proses Belajar
}

\author{
Ida Ayu Gede Bintang Praba Dewi dan Komang Rahayu Indrawati \\ Program Studi Psikologi, Fakultas Kedokteran, Universitas Udayana \\ bintangparabdewi@ymail.com
}

\begin{abstract}
Abstrak
Belajar merupakan proses atau kegiatan yang tidak akan berhenti dalam hidup manusia. Belajar dapat dilakukan oleh siapa saja dan dimana saja. Salah satu proses pembelajaran terjadi di lingkungan sekolah. Setiap siswa memiliki gaya belajar masing-masing yang sesuai dengan kenyamanan siswa. Hasil dari pembelajaran tersebut akan semakin bertambah apabila dibantu dengan media penyerta yaitu catatan. Mencatat termasuk dalam proses belajar apabila dilakukan dengan kesadaran sendiri tanpa paksaan dari individu lain. Sikap perilaku mencatat dapat membantu siswa dalam memahami sikap kemampuan memori pada proses belajar. Oleh karena itu peneliti ingin melihat hubungan antara sikap perilaku mencatat terhadap sikap kemampuan memori pada proses belajar.

Metodologi penelitian adalah kuantitatif, dengan menggunakan 166 subjek anak kelas 2 IPA SMA Negeri di Denpasar, dengan rentang umur 15 sampai 17 tahun. Koefisien korelasi dalam penelitian ini adalah 0,442 dengan probabilitas 0,000. Ini menunjukkan bahwa ada hubungan antara sikap perilaku mencatat terhadap sikap kemampuan memori pada proses belajar. Koefisien determinasi dalam penelitian ini adalah 0,195. Metode analisis yang digunakan pada penelitian ini adalah regresi sederhana. Hasil analisis statistik menunjukkan bahwa sikap perilaku mencatat dapat digunakan untuk memprediksi sikap kemampuan memori. Ketika individu memiliki sikap perilaku mencatat, maka individu akan dapat melihat sejauh mana sikap kemampuan memori dalam diri masing-masing individu.
\end{abstract}

Kata Kunci : Sikap Perilaku Mencatat, Sikap Kemampuan Memori, Siswa

\begin{abstract}
Learning is a process or activity that would not stop in a person lifetime. Learning can be done by anyone and anywhere. One of the learning process occur in the school environment. Each student has an individual learning style that suits their convenience. The result of the study will further improve if aided by the accompanying media that is taking notes. Taking notes is included in the learning process when done with awareness and without enforcement from others. Taking note behavior will help students understanding the perception of memory skill in learning process. Due to the reasons above, the researcher wants to look relationship between the attitude of taking note behavior towards the attitude of memory skill in learning process.

The research methodology is quantitative, used 166 subjects whom are grade 2 science, high school students in Denpasar, with 15 to 17 years old age range. The correlation coefficient is 0,442 with 0,000 probabilities. This mentioned results shows that there is a relationship between the attitude of taking note behavior towards the attitude of memory skill in learning process. The determination coefficient is 0,195 . The analysis method in this research is simple regression. Statistical analysis showed that the attitudes of taking note behavior can be used to predict attitudes of memory skill. When individuals have attitude of taking note behavior, then the individual will able to see as far as which the attitude of memory skill within each individual.
\end{abstract}

Keyword: Attitude of taking note behavior, Attitude of Memory Skill, Student 


\section{A. G. B. P. DEWI DAN K. R. INDRAWATI}

\section{LATAR BELAKANG}

Pendidikan adalah salah satu sarana dalam upaya mempersiapkan generasi muda sebagai penerus bangsa. Seringkali timbul permasalahan dan beberapa tantangan yang harus dilewati ketika hendak menghasilkan "orang-orang pintar". Salah satu permasalahan yang menjadi trend yaitu beberapa mata pelajaran yang dianggap sulit oleh sebagian siswa siswa dan menjadi momok yang menakutkan. Permasalahan kedua yaitu kurang efektifnya metode pembelajaran yang digunakan oleh siswa, karena kurang arahan dari guru. Menjawab kedua permasalahan ini, semua tantangan dituntut untuk ada solusi pemecahan. Dalam rangka meningkatkan mutu pendidikan, diperlukan beberapa inovasi dalam hal gaya belajar siswa. Belajar merupakan proses atau suatu kegiatan yang tidak akan berhenti dalam hidup manusia. Setiap langkah yang ditempuh siswa, terlihat dari bagaimana cara siswa memilih gaya pembelajaran masing-masing. Gaya belajar merupakan suatu kombinasi dari bagaimana individu menyerap lalu mengatur dan mengelola informasi (Porter \& Hernacki 2002). Hood dalam Tjundjing (2003) menjelaskan bahwa setiap individu memiliki gaya belajar yang berbeda, khususnya dalam menerima dan mengelola informasi yang menurut individu nyaman (Wulandari, 2009).

Gaya belajar termasuk faktor yang mendukung kesuksesan siswa pada saat proses belajar di dalam kelas. Penggunaan gaya belajar yang tepat dan sesuai dengan kemampuan siswa, akan mengakibatkan peningkatan dalam hal kemampuan memori. Pengetahuan siswa akan semakin bertambah ketika siswa mempelajari suatu materi baru dan ingatan diperkuat dengan media penyerta yaitu catatan. McCarthy (1997) \& Swisher \& Schoorman, (2001) dalam (Slavin, 2009) menjelaskan bahwa semua individu belajar dalam banyak hal, tetapi beberapa dari individu belajar lebih baik dalam beberapa hal dibandingkan individu lain. Menurut (Uno, 2010) salah satu karakteristik siswa dengan gaya belajar visual adalah sulit mengikuti pelajaran secara lisan dan seringkali salah mengintepretasikan kata atau ucapan, sehingga ada beberapa pendekatan yang dapat digunakan untuk mengatasi masalah yang dialami anak dengan visual learners, yaitu menggunakan beragam bentuk grafis berupa slide, gambar ilustrasi, coretan, kartu bergambar, catatan, dan kartu gambar berseri. Senada dengan pendapat Ummah (2012), hambatan yang dialami oleh siswa dalam tipe belajar visual adalah kurang mampu mengingat sesuatu yang disampaikan secara lisan, sehingga siswa membutuhkan media catatan untuk membantu pengulangan kembali dan mempertahankan ingatan. Catatan yang dibuat mencirikan siswa termasuk dalam teknik belajar visual, karena siswa fokus pada pengelihatan saat guru menjelaskan materi (Olivia, 2009). Menurut Murdock kelemahan ingatan juga terjadi ketika kata-kata secara verbal yang lebih banyak digunakan daripada huruf-huruf yang ditulis (Slavin, 2009). Pengertian catatan adalah kalimat standar adalah suatu catatan atau tulisan yang berasal dari apa yang dilihat, didengar atau apa yang dipikirkan (Suroso, 2004).

Porter \& Hernacki (2002) memaparkan ada dua teknik pencatatan yang sangat efektif, yaitu peta pikiran dan catatan TS (catatan tulis susun). Kedua cara ini memberikan kemudahan bagi siswa untuk dapat melihat gambaran secara luas dan membuat siswa memiliki pemahaman pelajaran serta daya ingat yang baik. Pemaparan mengenai teknik peta pikiran dan catatan tulis susun adalah mind mapping merupakan sejenis teknik merangkum suatu persoalan , sejarah, kejadian atau sesuatu yang memiliki topik. Dalam peta pikiran digunakan grafis dan ruang (gambar dan simbol) dan warna (Suroso, 2004). Penulisan catatan adalah mendengarkan apa yang dikatakan oleh individu lain kemudian membuat poin penting dari pembicaraan tersebut. Sedangkan penyusunan catatan berarti menuangkan pemikiran kita sendiri kedalam catatan setelah mendengar pembicaraan dari individu lain.

Mencatat dapat dikatakan bukan hal utama dalam sistem belajar mengajar, namun De Porter dan Hernacki (1999:14) berpendapat bahwa kegiatan mencatat sebagai salah satu kegiatan terpenting, karena selain meningkatkan daya ingat, catatan diperlukan untuk mengingat apa yang tersimpan dalam memori (Kompas, 2012). Pendapat tambahan diperoleh peneliti berdasarkan hasil wawancara dari beberapa ahli pendidikan yaitu mencatat berdasarkan sudut bahasa (linguistic) adalah sebuah kata jadian atau bentukan yang berasal dari kata dasar catat. Catat termasuk dalam kategori kata kerja yang bersinonim dengan tulis, yaitu membuat sebuah tulisan di dalam kertas atau menyimpannya di dalam memori. Mencatat yang dimaksud termasuk dalam sebuah proses dan kata dasar catat sering ditambahkan dengan akhiran -an, sehingga menjadi sebuah hasil (Suparwa, 2012).

Damayanti (2012) memaparkan yang dimaksud dengan mencatat adalah membuat tulisan yang berkaitan dengan informasi yang dilihat dan didengar. Mencatat yaitu menuliskan sesuatu yang penting, seperti meringkas. Purwani (2012) menjelaskan bahwa mencatat adalah melakukan suatu kegiatan atau mendengarkan informasi atau merekam data melalui daya tangkap, lalu kemudian dicatat. Mencatat adalah merekam data informasi yang senyatanya dilihat dan dipahami pada saat pelajaran berlangsung. Menurut Rahajeng (2012) mencatat dalam belajar visual tidak hanya menulis secara lisan, tetapi ditekankan juga ke dalam grafis, model mind mapping, penggunaan warna dan penataan letak. Mencatat merupakan suatu kegiatan menyalin informasi ke dalam bentuk tulisan (Perjuangan, 2012). Mencatat adalah salah satu strategi belajar untuk mengingat apa yang disampaikan pengajar. Mencatat juga sebagai self evaluation terhadap pemahaman yang dimiliki siswa terhadap pelajaran yang disampaikan (Kertiasih, 2012) 
Melatih ingatan dapat dilakukan dengan berbagai cara, salah satu media yang dapat membantu untuk meningkatkan daya ingat adalah dengan membuat sebuah catatan, seperti yang dikatakan dalam artikel (rahasia kebiasaan daya ingat kuat para jenius), penelitian dilakukan terhadap 29.500 individu yang memiliki daya tahan ingat kuat. Penelitian yang dilakukan oleh (Rostikawati, 2009) menyatakan salah satu usaha untuk meningkatkan daya ingat adalah dengan melakukan pencatatan pada saat mengikuti proses pembelajaran disekolah. Menurut Soemanto, mencatat sebagai bagian dari proses belajar adalah bila mencatat yang disertai dengan kesadaran, kebutuhan dan tujuan pencapaian belajar (Zainuddin, 2011). Ingatan individu tidak bertahan lama karena fenomena lazim yaitu menggunakan sistem "kebut semalam" dalam menghadapi ujian. Salah satu contoh yaitu Ujian Nasional yang dijadikan sebagai salah satu syarat kelulusan SMA juga menjadi momok yang menakutkan oleh setiap siswa. Dalam 3 tahun mereka menempuh sekolah, tetapi dalam 3 hari saja ditentukan "hidup dan matinya".

Individu yang tidak memanfaatkan penggunaan memori pada otak, akan memperbesar kemungkinan hilangnya satu persatu informasi yang tersimpan. Menurut (Porter \& Hernacki, 2002) banyak individu tampaknya kehilangan kemampuan untuk mengingat saat beranjak tua, karena individu berhenti "menandai". Dalam artian individu menganggap apa yang dilihat dan didengar kurang begitu penting, sehingga individu melewatkan begitu saja informasi yang diterima tanpa membuat suatu catatan. Albion dalam (Climenhaga, 2011) menyatakan penggunaan catatan sudah mulai ditinggalkan dan lebih dari $80 \%$ siswa tidak menggunakan catatan dalam proses belajar. Siswa mempunyai kebiasaan malas belajar dengan hal-hal yang detail, dan hanya menginginkan proses yang "instan" seperti misalnya meminjam catatan teman, atau meminta handout dari guru. Berbeda halnya dengan Pai-Lin, William, Hamman, dan Hendricks (2008) dari penelitian terhadap siswa kelas tiga sains, diketahui bahwa dengan mengambil catatan yang dinilai penting oleh siswa akan berguna untuk meningkatkan pemahaman atas apa yang diajarkan (Climenhaga, 2011). Dari penelitian tersebut diperoleh bahwa siswa mampu meningkatkan informasi dalam mata pelajaran dengan menggunakan media catatan.Para siswa akan mampu mengingat pelajaran lebih lama dibanding siswa yang hanya duduk dan mendengarkan.

Peneliti mengkhususkan melihat perilaku mencatat pada pelajaran matematika karena dari penelitian sebelumnya (Nurdaliana, Dimpudus, \& Sumarno, 2011) yang berada di SMPN 21 Samarinda mengatakan bahwa sekitar 30\% siswa memiliki skor matematika yang rendah yakni di bawah 60 . Penyebab nilai rendah pada skor matematika siswa adalah, siswa kurang memiliki minat dalam mempelajari matematika, catatan siswa kurang bervariasi dan tidak menarik untuk dipelajari sehingga siswa mengalami kesulitan dalam mempelajari kembali catatan pelajaran matematika. Maraknya kontoversi dalam pendidikan matematika juga menjadi acuan untuk mengkhususkan penelitian gaya belajar mencatat. Santrock (2007), mengatakan bahwa kebanyakan individu menganggap matematika adalah bidang hitung-menghitung dan para ahli memandang perhitungan adalah alat dalam matematika. Tujuan para guru memberikan instruksi pada pelajaran matematika adalah agar siswa dapat merefleksikan apa yang dianggap penting dan menemukan cara terbaik bagi para siswa untuk mempelajari matematika.

Pada penelitian sebelumnya mengenai "Strategi Membangun Metakognisi Siswa SMA dalam Pemecahan Masalah Matematika" dikatakan bahwa matematika merupakan ilmu universal yang mendasari perkembangan beberapa teknologi modern dan mempunyai peran yang penting dalam berbagai disiplin ilmu untuk memajukan daya pikir manusia. Pelajaran matematika yang diberikan pada pendidikan sekolah menengah dimaksudkan untuk membekali siswa kemampuan berfikir yang logis, sistematis dan kritis, serta kemampuan untuk bekerjasama. Berdasarkan pemaparan para ahli, maka pelajaran matematika yang diperoleh siswa pada proses belajar sangat penting untuk menunjang pembelajaran lainnya.

Menurut Crow dalam (Purba, 2009) kebiasaankebiasaan membuat ringkasan bahan pelajaran atau membuat catatan-catatan fakta yang sukar dan penting biasanya sangat bermanfaat. Siswa yang memiliki daya ingat yang kurang baik dapat belajar dari catatan yang dibuat dan kreasikan sendiri. Metode pencatatan akan dapat membantu siswa mengingat materi yang diberikan guru, karena siswa memiliki beberapa tambahan informasi pelajaran. Tipe mencatat memberikan kesempatan kepada siswa untuk memperluas keaktifan di dalam kelas. Saat guru memberikan materi, siswa yang memiliki tipe belajar visual akan menggunakan metode mencatat. Menurut Jeannette VOS (Suroso, 2004) individu belajar dengan visual biasanya duduk tegak dan mengikuti guru dengan matanya. Tipe mencatat dilakukan dengan cara pada saat guru menerangkan mata pelajaran di dalam kelas, siswa akan menulis ulang atau menyalinnya di buku masingmasing. Berdasarkan latar belakang permasalahan diatas, peneliti tertarik untuk melihat bagaimana sikap perilaku mencatat terhadap sikap kemampuan memori pada proses belajar.

\section{METODE}

\section{Variabel dan definisi operasional}

Menurut Kountur (2004) variabel menunjukkan suatu arti yang dapat membedakan antara sesuatu dengan yang lain. Variabel umum yang sering digunakan yaitu variabel bebas dan variabel tergantung (Umar, 2002). Variabel Independen (bebas) adalah variabel yang menjelaskan atau mempengaruhi 


\section{A. G. B. P. DEWI DAN K. R. INDRAWATI}

variabel lain. Variabel dependen (tergantung) adalah variabel yang dijelaskan atau yang dipengaruhi oleh variabel independen (bebas). Variabel bebas (IV) pada penelitian ini adalah sikap perilaku mencatat dan sikap kemampuan memori sebagai variabel tergantung (DV).

Definisi operasional mengenai sikap perilaku mencatat adalah derajat yang menentukan afek positif dan negatif yang dirasakan individu terhadap informasi yang didengar dan dilihat atas apa yang dilakukan atau dibicarakan oleh individu lain, kemudian menuliskan kembali informasi yang didengar dan dilihat ke dalam suatu bentuk tulisan. Pada penelitian ini, sikap perilaku mencatat dapat diukur melalui kuesioner yang disusun sendiri oleh peneliti. Kuesioner sikap perilaku mencatat terdiri dari lima kriteria yaitu tulisan, warna, penataan letak, peta konsep atau peta konsep atau mind mapping, ringkasan.

Definisi operasional sikap kemampuan memori adalah derajat yang menentukan afek positif dan negatif yang dirasakan individu terhadap suatu objek psikologis terhadap kemampuan mengingat kembali informasi yang tersimpan di dalam ingatan siswa dan telah dipelajari sebelumnya. Sikap kemampuan memori akan diukur dengan kuesioner yang disusun sendiri oleh peneliti berdasarkan empat kriteria yaitu : ingatan jangka pendek, ingatan jangka panjang, waktu dan pemanggilan kembali (retrieval) .

\section{Responden}

Menurut Sukandarrumidi (2004) populasi adalah keseluruhan objek penelitian baik terdiri dari benda yang nyata, abstrak, peristiwa ataupun gejala yang merupakan sumber data dan memiliki karakter tertentu dan sama. Penelitian menggunakan populasi siswa SMA Negeri di Denpasar. Sampel merupakan bagian dari jumlah dan karakteristik yang dimiliki oleh populasi. Menurut Sukandarrumidi (2004) sampel adalah bagian dari populasi yang memiliki sifat-sifat yang sama dari objek yang merupakan sumber data. Sampel yang diambil dari populasi harus representatif artinya benar-benar bisa mewakili populasi. Pada penelitian ini sampel yang diambil adalah siswa kelas II IPA SMA Negeri di Denpasar usia 15 sampai 17 tahun.

Metode pengambilan sampel yang digunakan dalam penelitian ini adalah purposive sampling. Teknik sampling ini dilakukan dengan yaitu pengambilan sampling berdasarkan beberapa kriteria yang dibuat oleh peneliti sendiri untuk melihat tujuan dari penelitian ini (Sukandarrumidi, 2004).

\section{Tempat penelitian}

Responden dalam penelitian ini merupakan siswa SMA Negeri kelas II IPA usia 15 sampai 17 tahun di kota Denpasar. Cakupan wilayah Denpasar yang dipilih oleh peneliti karena Denpasar merupakan ibu kota strategis dengan kelebihan masing-masing sekolah. Alasan peneliti menggunakan siswa SMA usia 15 sampai 17 tahun adalah berdasarkan teori perkembangan kognitif Piaget, individu sudah mencapai tahap operasional formal pada usia remaja akhir yaitu 15 sampai 20 tahun (Santrock, 2007). Artinya siswa sudah mengerti konsep dan dapat berpikir secara kongkrit maupun abstrak. Peneliti memilih siswa kelas kelas II jurusan IPA, karena peneliti fokus pada mata pelajaran matematika yang diajarkan di kelas IPA.

Berdasarkan hasil proses pengambilan sampel dengan purposive sampling terpilih sekolah SMA Negeri 1, SMA Negeri 2, SMA Negeri 3, SMA Negeri 6, dan SMA Negeri 7 di Denpasar. Dalam menentukan jumlah sampel minimum pada penelitian ini menggunakan rumus populasi tidak diketahui yaitu Kountur (2004) sehingga diperoleh hasil jumlah sampel pada penelitian ini adalah 16 siswa.

\section{Alat ukur}

Pada penelitian ini menggunakan skala Likert sebagai alat ukur. Menurut Kinnear skala Likert berhubungan dengan pernyataan tentang sikap individu terhadap sesuatu (Umar, 2002). Skala sikap perilaku mencatat merupakan skala yang dibuat oleh peneliti untuk mengukur gaya belajar visual dengan teknik mencatat yang digunakan oleh siswa. Skala ini terdiri dari penyataan favorable dan unfavorable dan terdapat 5 kriteria yaitu tulisan, warna, penataan letak, peta konsep atau mind mapping dan ringkasan

Skala kedua yaitu Skala sikap kemampuan memori terdiri dari pernyataan favorable dan unfavorable dan terdapat 4 kriteria yaitu ingatan jangka pendek, ingatan jangka panjang, waktu dan pemanggilan kembali. Pada penelitian ini skala sikap perilaku mencatat dan skala sikap kemampuan memori terdiri dari empat alternatif jawaban, pada penyataan favorable Sangat Setuju diberi nilai empat, Setuju diberi nilai tiga, Tidak Setuju diberi nilai dua dan Sangat Tidak Setuju diberi nilai satu. Pada pernyataan unfavorable Sangat Setuju diberi nilai satu, Setuju diberi nilai dua, Tidak Setuju diberi nilai tiga dan Sangat Tidak Setuju diberi nilai empat.

\section{Metode pengumpulan data}

Metode pengumpulan data pada penelitian ini adalah dengan menggunakan dua kuesioner. Kuesioner Sikap Perilaku Mencatat dan kuesioner Sikap Kemampuan Memori. Kuesioner sikap perilaku mencatat digunakan untuk melihat sikap subjek dalam penelitian ini termasuk dalam gaya belajar visual khususnya dengan teknik mencatat dengan menggunakan kuesioner dengan bentuk pernyataan yang disusun sendiri oleh peneliti. Kuesioner Sikap Kemampuan Memori digunakan untuk melihat seberapa besar sikap 
individu terhadap kemampuan memori khususnya dalam pelajaran matematika. Dalam kuesioner sikap perilaku mencatat dan sikap kemampuan memori terdapat lembaran identitas mengenai subjek dan arahan mengenai cara menjawab kuesioner.

\section{Teknik analisis data}

Dalam teknik analisis data, validitas yang digunakan adalah validitas konstruk dan validitas isi. Menurut Sugiyono (2005) validitas menunjukkan sejauh mana instrumen penelitian dapat digunakan untuk mengukur apa yang hendak diukur. Dalam penelitian ini, peneliti menggunakan validitas isi dan validitas konstruk. Validitas isi adalah suatu pengukur untuk mengetahui sejauh mana isi alat pengukur validitas mewakili seluruh aspek yang dianggap sebagai aspek kerangka konsep (Umar, 2002). Menurut Azwar (2006) validitas isi merupakan validitas yang diestimasi melalui pengujian terhadap isi tes dengan analisis rasional atau dengan menggunakan professional judgement. Peneliti menggunakan professional judgement untuk membantu mengetahui kesahihan isi suatu alat ukur dengan membuang kalimat yang tidak relevan dengan tujuan penelitian.

Validitas konstrak adalah tipe validitas yang menunjukkan sejauh mana tes mengungkap suatu trait atau konstrak teoritik yang hendak diukur (Allen \& Yen, 1979) dalam (Azwar, 2006). Uji validitas pada penelitian ini menggunakan bantuan program SPSS 16. Analisis ini dengan cara mengkorelasikan masing-masing skor aitem dengan skor total. Aitem yang memiliki validitas konstruk yang baik dapat diketahui dengan menggunakan tabel korelasi Product Moment skor rhitung, kemudian dibandingkan dengan nilai korelasi rtabel. Apabila rhitung, > rtabel, maka aitem tersebut dinyatakan valid. Pada penelitian ini item dinyatakan valid apabila memiliki skor rhitung, diatas 0,20 (Nurgiyantoro, Gunawan, \& Marzuki, 2009).

Reliabilitas adalah konsistensi skor yang dicapai oleh individu yang sama ketika mereka diuji ulang dengan tes yang sama pada kesempatan yang berbeda (Anastasi \& Urbina, 2007). Dalam penelitian ini pengujian reliabilitas menggunakan dengan teknik Alfa Cronbach dengan bantuan program SPSS 16 (Sugiyono, 2005). Semakin besar koefisien reliabilitas Alpha maka semakin kecil kesalahan skala yang digunakan, dan semakin kecil nilai koefisien reliabilitas alpha, maka semakin tidak reliabel alat ukur yang digunakan. Pada penelitian ini, nilai reliabilitas yang digunakan oleh peneliti mengacu pada alat ukur yang memiliki nilai reliabilitas diatas 0,600 (Arikunto,1993).

Pada penelitian ini metode analisis data dilakukan secara kuantitatif yaitu menggunakan regresi linear sederhana. Menurut Usman (2006) guna analisis regresi sederhana adalah untuk mendapatkan hubungan antara dua variabel atau lebih, untuk mendapatkan pengaruh antara variabel dependen terhadap variabel independen dan untuk meramalkan pengaruh variabel dependen terhadap variabel independen. Dalam melakukan analisis regresi linear sederhana terdapat dua syarat yang harus terpenuhi, yaitu uji asumsi berupa uji normalitas dan linearitas.

Uji normalitas digunakan untuk mengetahui apakah subjek berasal dari populasi yang berdistribusi normal atau tidak. Dalam penelitian ini menggunakan uji statistik Kolmogorov Smirnov. Konsep dasar dari uji normalitas Kolmogorov Smirnov adalah dengan membandingkan distribusi data (yang akan diuji normalitasnya) dengan distribusi normal baku. Uji Normalitas Kolmogorov Smirnov dengan Program SPSS 16. Jika $\mathrm{p}$ lebih besar 0,05 menunjukkan data berdistribusi normal. Uji linearitas dilakukan sebagai salah satu syarat untuk melakukan uji regresi. Uji linearitas garis regresi dilakukan dengan menghitung nilai F. Uji linearitas dilakukan untuk mengetahui apakah dua variabel yang diuji menunjukkan hubungan yang linear atau tidak (Priyatno, 2012). Pada penelitian ini, menggunakan Uji Linearitas dengan bantuan komputasi SPSS 16 (compare means). Jika p lebih kecil dari 0,05, maka garis regresi data skor variabel independen dan dependen dinyatakan linear (Nurgiyantoro, Gunawan, \& Marzuki, 2009).

\section{HASIL PENELITIAN}

Dalam metode pengumpulan data, peneliti menggunakan tryout terpakai yaitu kuesioner disebarkan kepada subjek tryout dan subjek tryout tersebut sekaligus sebagai subjek penelitian. Pengambilan sampel dimulai dari tanggal 20 Desember 2012 sampai 4 Januari 2013. Kendala yang dialami peneliti pada saat awal penyebaran kuesioner adalah sulit mendapatkan subjek anak SMA, karena siswa SMA masih dalam suasana libur semester. Berdasarkan hasil pengujian validitas dan reliabilitas koefisien alpha pada skala sikap perilaku mencatat diperoleh uji coba kesahihan 30 aitem pada skala sikap perilaku mencatat diperoleh koefisien korelasi yang bergerak dari 0,085 sampai 0,586 dan 3 aitem yang gugur dari 30 aitem yang diuji, sehingga jumlah aitem yang sahih adalah 27 aitem. Kemudian peneliti menggugurkan 3 aitem yang tidak sahih tersebut sehingga diperoleh koefisien korelasi yang bergerak dari 0,216 hingga 0,601. Uji Reliabilitas adalah suatu uji yang dilakukan untuk melihat apakah instrumen yang digunakan untuk mengumpulkan data konsisten dalam memberikan penilaian atas apa yang diukur (Kountur, 2004). Pada penelitian skala sikap perilaku mencatat dilakukan uji reliabilitas dengan Alpha Cronbach's dan diperoleh hasil yang signifikan, dengan membuang aitem yang tidak memenuhi syarat yaitu dibawah 0,20. Koefisien reliabilitas Alpha $(\alpha)$ skala sikap perilaku mencatat dengan menggugurkan aitem-aitem adalah 0,860 , nilai ini sudah 


\section{A. G. B. P. DEWI DAN K. R. INDRAWATI}

mencukupi syarat reliabilitas dan menunjukkan bahwa skala ini memiliki nilai $86 \%$ untuk mengukur apa yang ingin peneliti ungkap (Arikunto, 1993).

Pada saat uji coba skala sikap kemampuan memori dengan 24 aitem, diperoleh koefisien korelasi yang bergerak dari 0,129 hingga 0,588 dan terdapat 3 aitem yang gugur karena koefisien korelasinya berada dibawah 0,20. Dari 24 aitem tersebut hanya 21 aitem yang sahih dengan koefisien korelasi yang bergerak dari 0,230 sampai 0,622 dan nilai reliabilitas sebesar 0,851 . Hasil uji reliabilitas skala sikap kemampuan memori diperoleh koefisien alpha $(\alpha)$ 0,851 yang menyatakan bahwa dengan skala sikap kemampuan memori $85 \%$ dapat digunakan untuk pengambilan data dan dapat digunakan untuk mengukur apa yang ingin peneliti ukur, karena sudah memenuhi nilai reliabilitas (Arikunto, 1993).

Pada uji normalitas dengan menggunakan 176 subjek, diperoleh nilai $\mathrm{Z}$ sikap perilaku mencatat adalah 1.511 dan memiliki probabilitas ( $\mathrm{p}>0,05$ yaitu $0,021>0,05$ ) artinya data berdistribusi normal, sedangkan untuk nilai $\mathrm{Z}$ sikap kemampuan memori adalah 1.926 dan memiliki probabilitas ( $\mathrm{p}<0,05$ yaitu $0,001<0,05$ ) artinya data berdistribusi tidak normal. Hal ini menunjukkan bahwa data pada variabel sikap perilaku mencatat berdistribusi normal, sedangkan variabel sikap kemampuan memori berdistribusi tidak normal, dan belum dapat memenuhi syarat regresi linear sederhana. Oleh karena itu peneliti membuat data pada variabel sikap kemampuan memori menjadi normal dengan menyisihkan subjek yang berada pada ekstrim tinggi dan rendah atau outlire (Weisberg, 2005). Peneliti memperoleh 10 subjek dalam kuesioner Sikap Perilaku Mencatat dan Sikap Kemampuan Memori yang harus digugurkan, sehingga untuk membentuk data yang normal digunakan 166 jawaban subjek.

Hasil uji normalitas diatas menyatakan nilai $\mathrm{Z}$ (kolmogorov smirnov) Sikap Perilaku Mencatat adalah 1.269 dengan probabilitas ( $\mathrm{p}>0,05$ yaitu $0,080>0,05$ ) dan nilai $\mathrm{Z}$ (kolmogorov smirnov) Sikap Kemampuan Memori sebesar 1.215 dengan probabilitas ( $\mathrm{p}>0,05$ yaitu $0,105>0,05$ ). Kedua nilai probabilitas tersebut lebih besar dari 0,05 sehingga variabel sikap perilaku mencatat dan sikap kemampuan memori diasumsikan normal, dan syarat regresi linear sederhana terpenuhi. Uji linear dilakukan dengan mencari persamaan garis dari variabel bebas dan variabel tergantung. Uji Linearitas pada penelitian ini menggunakan bantuan SPSS 16 dan dianggap linear apabila $\mathrm{p}<0,05$ (Nurgiyantoro, Gunawan, \& Marzuki, 2009). Analisis data pada uji linearitas menunjukkan bahwa hubungan kedua variabel bersifat linear karena memiliki probabilitas (p) sebesar 0,000 atau memiliki taraf signifikansi lebih kecil dibandingkan 0,05 $(\mathrm{p}<0,05)$ dan data diasumsikan linear. Dengan terpenuhinya syarat uji asumsi ini maka teknik analisis data dengan menggunakan regresi linear sederhana dapat dilakukan.

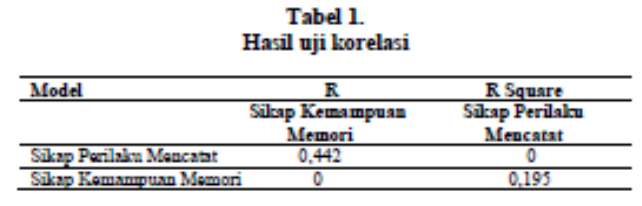

Hasil perhitungan uji korelasi menggunakan bantuan SPSS 16 diperoleh korelasi (r) sebesar (+) 0,442. Angka R sebesar 0,442 menunjukkan adanya korelasi atau hubungan antara sikap perilaku mencatat dan sikap kemampuan memori. Tanda (+) menunjukkan bahwa semakin tinggi sikap terhadap perilaku mencatat yang digunakan siswa, maka akan semakin tinggi sikap kemampuan memori siswa pada proses belajar. Hasil perhitungan uji korelasi menggunakan bantuan SPSS 16 diperoleh korelasi (R) sebesar (+) 0,442. Angka R sebesar 0,442 menunjukkan adanya korelasi atau hubungan antara sikap perilaku mencatat terhadap sikap kemampuan memori pada proses belajar. Tanda (+) menunjukkan bahwa semakin tinggi sikap terhadap sikap perilaku mencatat yang digunakan siswa, maka akan semakin tinggi sikap kemampuan memori siswa pada proses belajar.

Nilai P yang bernilai 0,000 menunjukkan bahwa $\mathrm{Ha}$ diterima yaitu ada hubungan yang positif dan signifikan antara sikap perilaku mencatat terhadap sikap kemampuan memori pada proses belajar. Angka R Square pada tabel diatas adalah 0,195 berasal dari $(0,442) 2$, ini berarti bahwa 0,195 atau 19,5 $\%$ variasi dari sikap kemampuan memori dapat dijelaskan oleh sikap perilaku mencatat. Dalam penelitian ini, sumbangan dari variabel sikap perilaku mencatat terhadap sikap kemampuan memori adalah sebesar 19,5\%., sedangkan sisa dari $80,5 \%$ disumbangkan oleh faktor-faktor lain.

\section{Tabel 2.}

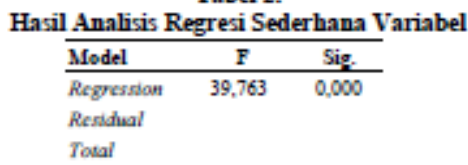

Berdasarkan tabel diatas, kita dapat melihat hasil uji F Hitung adalah 39,763 dan tingkat signifikansi adalah 0,000. Tingkat signifikansi sebesar 0,000 lebih kecil dari pada 0,05 $(0,000<0,05)$ menyatakan bahwa variabel sikap perilaku mencatat dapat digunakan untuk memprediksi sikap kemampuan memori pada proses belajar.

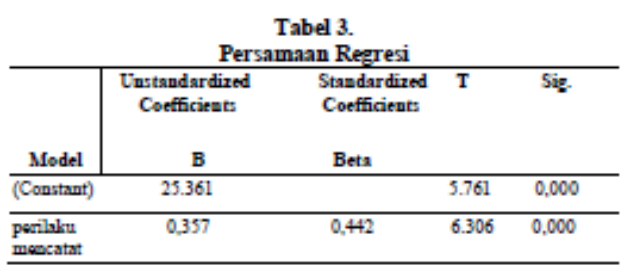

Adapun hasil uji dalam persamaan regresi diperoleh nilai t hitung sikap kemampuan memori adalah 5.761 dengan 
signifikansi 0,000 dan nilai t hitung sikap perilaku mencatat adalah 6.306 dengan nilai signifikansi 0,000. Nilai signifikasi kurang dari 0,05 dapat menyatakan bahwa penambahan pada variabel independen akan menyebabkan terjadinya penambahan pada variabel dependen. Persamaan regresi yang diperoleh dari tabel diatas adalah adalah $(\mathrm{y}=\mathrm{a}+\mathrm{bx})$ sehingga $\mathrm{y}=25.361+0,357 \mathrm{x}$. Persamaan ini dapat diartikan semakin adanya peningkatan satu nilai pada variabel sikap perilaku mencatat, maka satu nilai pada variabel sikap kemampuan memori juga akan cenderung meningkat.

Peneliti melakukan analisis tambahan yaitu pengkategorisasian subjek untuk menempatkan subjek dalam beberapa rentang. Penelitian ini disusun dengan lima rentang yaitu sangat rendah, rendah, sedang, tinggi, dan sangat tinggi. Adapun pembagiannya yaitu pada skala sikap perilaku mencatat dan skala sikap kemampuan memori adalah sebagai berikut:

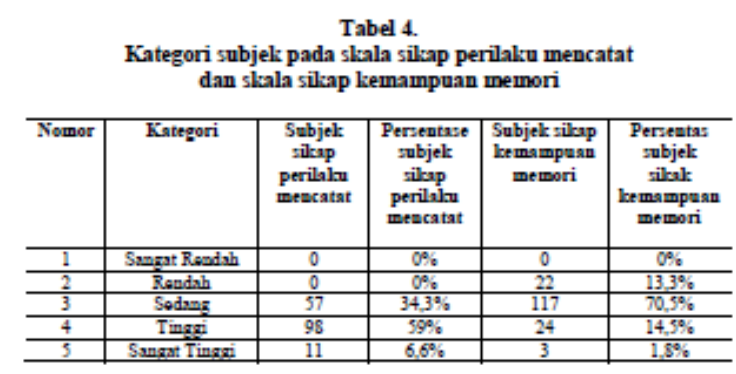

Tabel kategorisasi diatas menunjukkan jumlah subjek yang berada pada rentang sangat rendah dan rendah nihil, kategori sedang 57 subjek dengan persentase 34,3\%, kategori tinggi 98 subjek dengan persentase $59 \%$ dan kategori sangat tinggi 11 subjek dengan persentase 6,6\%. rentang subjek yang berada pada kategori sangat rendah yaitu nihil, kategori rendah 22 subjek dengan persentase 13,3\%, kategori sedang 117 subjek dengan persentase 70,5\%, kategori tinggi 24 subjek dengan persentase $14,5 \%$ dan sangat tinggi 3 subjek dengan persentase $1,8 \%$.

\section{PEMBAHASAN}

Individu dalam penelitian ini adalah siswa, merupakan salah satu aset penerus bangsa yang sangat membutuhkan pendidikan. Pendidikan dapat ditempuh disekolah dengan masing-masing sistem pembelajaran, sehingga siswa mampu mengembangkan kreativitas serta ilmu pengetahuan siswa. Berbagai cara yang digunakan oleh sekolah untuk dapat membantu kelancaran proses belajar mengajar, salah satu cara yaitu dengan menggunakan gaya belajar yang tepat. Pada penelitian ini, peneliti mengkhususkan melihat gaya belajar visual dengan teknik mencatat. Data analisis yang diperoleh pada penelitian ini menyatakan, hipotesis alternatif pada penelitian ini diterima, yaitu ada hubungan antara sikap perilaku mencatat terhadap sikap kemampuan memori pada proses belajar. Penerimaan hipotesis pada penelitian ini berdasarkan hasil analisis statistik dengan menggunakan teknik regresi linear sederhana, yaitu koefisien korelasi (R) antara variabel sikap perilaku mencatat dan sikap kemampuan memori adalah 0,442. Koefisien korelasi pada penelitian ini sudah memenuhi syarat untuk dapat dikatakan memiliki hubungan, karena $\mathrm{p}$ lebih besar dari $0,05$ ( $p>0,05)$, yang artinya variabel sikap perilaku mencatat dan sikap kemampuan memori berkorelasi positif dan signifikan. Apabila terjadi penambahan nilai pada variabel sikap perilaku mencatat, maka akan menyebabkan penambahan nilai pada variabel sikap kemampuan memori.

Koefisien determinasi (R2) pada penelitian ini menunjukkan angka 0,195, artinya sikap perilaku mencatat memberikan sumbangan sebesar $19,5 \%$ terhadap sikap kemampuan memori dan ada faktor-faktor lain yang tidak diteliti dalam penelitian ini. Berdasarkan hasil sumbangan sikap perilaku mencatat terhadap sikap kemampuan memori yang tidak terlalu besar, peneliti menyadari keterbatasan skala sikap perilaku mencatat tunggal bukan merupakan satusatunya alat yang dapat digunakan untuk mengumpulkan data penelitian. Individu belajar dengan cara yang berbeda-beda, dan semua memiliki kelebihan dan kekurangan. Masingmasing cara memiliki kekuatan tersendiri, dan dalam kenyataannya semua individu memiliki tiga gaya belajar yaitu visual, auditori dan kinestetik. Hanya saja umumnya individu akan menggunakan satu gaya belajar yang dominan (Rose dan Nicholl, dalam Deporter, Reardon, \& Singer-Nourie, 1999). Pendapat ini menguatkan hasil sumbangan efektif yang diperoleh pada penelitian ini yaitu 19,5\%. Hal ini menunjukkan bahwa teknik mencatat tunggal belum mampu memberikan kontribusi yang besar terhadap kemampuan memori.

Kemampuan memori yang baik, dapat diperoleh jika individu secara sadar memasukkan makna dan asosiasi dari informasi yang diterima, dan untuk memaksimalkan informasi tersebut, individu harus membuat informasi menjadi bermakna dalam artian memberi makna pribadi. Agar informasi pelajaran lebih tahan lama pada memori, siswa harus menyesuaikan gaya belajar dengan kemampuan otak. Penyesuaian gaya belajar dengan kemampuan otak dapat dikatakan menjadi faktor lain yang mempengaruhi memori. Seperti yang dikatakan Williams dan Dunn dalam (Ghufron \& Rini Risnawita, 2012) menjelaskan bahwa ada sembilan bentuk kemampuan otak yang sesuai dengan belajar yaitu:

a) Informasi yang diperoleh berhubungan dengan kehidupan nyata, yang artinya pelajaran yang sesuai dengan kehidupan sehari-hari akan lebih melekat.

b) Perlunya motivasi untuk bisa memperkuat informasi yang masuk di dalam ingatan, individu membutuhkan dukungan 


\section{A. G. B. P. DEWI DAN K. R. INDRAWATI}

dan kesadaran dari diri sendiri dalam memahami suatu pelajaran.

c) Proses belajar disekolah akan lebih masuk kedalam otak siswa apabila melalui pengalaman langsung, siswa dapat mencerna pelajaran dengan baik ketika sudah pernah mengalaminya.

d) Belajar memerlukan penghubung informasi baru sebelum menerima pelajaran lainnya, guru memiliki peran yang besar dalam membentuk hubungan ini.

e) Pengelompokan informasi, artinya informasi dibagi menjadi beberapa sub unit sehingga otak bisa membentuk sebuah peta konsep.

f) Pengulangan kembali atau refleksi yaitu berfikir tentang apa yang telah dipelajari dan mencatat kembali.

g) Pada saat menerima pelajaran, siswa harus dalam kondisi yang sehat, pikiran harus sehat demi memperkaya memori di dalam ingatan.

h) Faktor lingkungan juga dapat mempengaruhi penerimaan informasi, khususnya pada lingkungan yang sedang berkembang, di harapkan sekolah memiliki akses untuk berita-berita terbaru.

i) Belajar adalah aktivitas yang memerlukan energi yang tinggi, setiap menerima pelajaran baru hendaknya siswa langsung berlatih agar informasi tersebut tidak pudar.

Menurut Cole \& Scribner, faktor pendidikan dapat memberikan pengaruh terhadap kemampuan memori yaitu dalam kesalahan penggunaan strategi untuk mengingat informasi berhubungan dengan kurangnya pendidikan di sekolah. Menururt Misty \& Rogoff faktor kebudayaan memiliki peran terhadap kemampuan individu untuk mempertahankan memori. Kebudayaan yang dimiliki individu, membuat individu semakin menjadi sensitif terhadap objek, kejadian dan strategi yang berhubungan dengan kemampuan memori (Santrock, 2004).

Sumbangan efektif sebesar $19,5 \%$ dari sikap perilaku mencatat dianggap memiliki kontribusi yang rendah terhadap sikap kemampuan memori. Sumbangan variabel sikap perilaku mencatat yang rendah terhadap sikap kemampuan memori diperkuat oleh hasil penelitian sebelumnya yang dilakukan oleh Pai-Lin, William, Hamman, dan Hendricks. Penelitian Pai-Lin dkk, menggunakan siswa kelas 3 sains sebagai subjek. Hasil dari penelitian Pai-Lin dkk, yaitu siswa mampu meningkatkan informasi dalam mata pelajaran dengan menggunakan media catatan (Climenhaga, 2011). Penelitian lain yang sejalan dengan penelitian sikap perilaku mencatat terhadap sikap kemampuan memori pada proses belajar adalah The Liang Gie, yang menunjukkan bahwa siswa akan sia-sia mengikuti proses belajar apabila tidak menggunakan media pencatatan, karena kapasitas memori yang terbatas (Salirawati, 2008).

Siswa yang menggunakan gaya belajar visual khususnya teknik mencatat, dapat dikatakan memiliki tingkat kemampuan memori yang lebih tinggi dibandingkan siswa yang tidak mencatat. Dengan gaya belajar visual khususnya teknik mencatat, siswa bisa merekam apa yang dilihat dan didengar, kemudian dituliskan kembali ke dalam bentuk catatan sesuai dengan gaya tulisan siswa masing-masing. Ketika adanya pemanggilan kembali (retrieval) mengenai informasi yang dipelajari tersebut, siswa yang menggunakan teknik mencatat akan lebih paham dan ingat dengan materi itu (Purwani, 2012). Peneliti membuat data tambahan yaitu deskripsi data yang berisi perbandingan antara mean empiris dan mean teoritis. Pada penelitian ini, diperoleh mean empiris sikap perilaku mencatat 77,36 dan mean empiris sikap kemampuan memori 53,01 lebih besar dibandingkan mean teoritis sikap perilaku mencatat 67,5 dan mean teoritis sikap kemampuan memori 52,5. Nilai mean empiris skala sikap perilaku mencatat dan sikap kemampuan memori yang lebih besar dari mean teoritis, menyatakan bahwa rata-rata subjek dalam penelitian ini memiliki kecenderungan sikap perilaku mencatat yang tinggi dan juga kecenderungan sikap kemampuan memori yang sedang, dilihat dari hasil kategorisasi. Hasil perbandingan mean empiris dan mean teoritis menguatkan hipotesis yang terjawab pada penelitian ini, yaitu semakin tinggi sikap terhadap sikap perilaku mencatat yang dilakukan, maka sikap kemampuan memori siswa akan cenderung meningkat.

Selain itu, peneliti juga membuat sebuah kategorisasi data untuk menempatkan subjek dalam beberapa rentang. Penelitian ini disusun dengan lima rentang yaitu sangat rendah, rendah, sedang, tinggi, dan sangat tinggi. Adapun pembagiannya yaitu pada skala sikap perilaku mencatat diperoleh jumlah subjek yang berada pada rentang sedang yaitu 57 individu 34,3\%, tinggi 98 individu 59\% dan sangat tinggi 11 individu 6,6\%. Hasil kategorisasi subjek pada skala sikap perilaku mencatat menyatakan subjek yang paling banyak terdapat pada rentang tinggi. Sedangkan untuk skala sikap kemampuan memori, peneliti memperoleh hasil kategorisasi, rendah 22 individu 13,3\%, sedang 117 individu $70,5 \%$, tinggi 24 individu 14,4\% dan sangat tinggi 3 individu $1,8 \%$. Hal ini menunjukkan bahwa rata-rata subjek memiliki kecenderungan sikap kemampuan memori yang sedang. Berdasarkan hasil kategorisasi yang dilakukan, diketahui bahwa kecenderungan subjek pada penelitian ini yang mempunyai kecenderungan sikap perilaku mencatat secara umum tergolong tinggi, dan kecenderungan sikap kemampuan memori subjek secara umum tergolong sedang.

Berdasarkan hasil penelitian yang diperoleh, peneliti menyadari keterbatasan pada penelitian ini, yaitu saat pemilihan waktu pengambilan sampel yang tidak tepat yaitu saat siswa dalam masa liburan, sehingga peneliti menggunakan tryout terpakai. Penyebaran kuesioner juga dibantu oleh beberapa kerabat, sehingga peneliti tidak mampu mengontrol kriteria subjek yang tepat pada penelitian ini. 
Adanya beberapa subjek yang tidak teliti dalam membaca petunjuk yang memungkinkan subjek tidak serius dalam mengerjakan kuesioner, oleh karena itu, memerlukan pengawasan dari peneliti agar kedepannya tidak terjadi kesalahan dalam memahami isi kuesioner. Berdasarkan hasil analisis data dan pembahasan yang telah dikemukakan, dapat disimpulkan bahwa hipotesis alternatif yang terjawab adalah ada hubungan antara sikap perilaku mencatat terhadap sikap kemampuan memori pada proses belajar. Angka koefisien dan korelasi positif pada penelitian ini menandakan bahwa terdapat hubungan yang positif dan signifikan antara sikap perilaku mencatat terhadap sikap kemampuan memori pada proses belajar. Hubungan positif berarti bahwa semakin tinggi sikap terhadap perilaku mencatat yang digunakan oleh siswa, maka sikap kemampuan memori siswa akan cenderung meningkat.

Hasil analisis regresi sederhana variabel yaitu uji $\mathrm{F}$ menunjukkan tingkat signifikansi yang menyatakan bahwa variabel sikap perilaku mencatat dapat digunakan untuk memprediksi sikap kemampuan memori. Ketika individu memiliki sikap perilaku mencatat, maka individu akan dapat melihat sejauh mana sikap kemampuan memori dalam diri masing-masing individu. Dalam hasil uji persamaan regresi linear sederhana diperoleh bahwa jika variabel sikap perilaku mencatat mengalami penambahan nilai, maka variabel sikap kemampuan memori akan cenderung mengalami penambahan nilai. Koefisien korelasi (R2) pada penelitian ini menunjukkan sumbangan efektif sikap perilaku mencatat terhadap sikap kemampuan memori. Sumbangan efektif yang tidak terlalu besar pada penelitian ini menunjukkan bahwa skala sikap perilaku mencatat tunggal belum mampu digunakan sebagai satu-satunya alat pengumpul data. Penelitian ini juga menyertakan data yang menunjukkan perbandingan antara mean teoritis dan mean empiris pada variabel sikap perilaku mencatat dan sikap kemampuan memori. Sehingga diperoleh hasil bahwa subjek dalam penelitian ini memiliki kecenderungan sikap perilaku mencatat yang tinggi dan sikap kemampuan memori yang sedang.

\section{DAFTAR PUSTAKA}

Arikunto, S. (1993). Manajemen Penelitian. Jakarta: PT. Rineka Cipta.

Azwar, S. (2006). Reliabilitas dan Validitas (Edisi Ketiga). Yogyakarta: Pustaka Pelajar.

Climenhaga, S. J. (2011). The Effect of Using Guided Notes for at Risk High School Science Student. a professional paper for a degree (master of science), 4.

Damayanti, Y. (2012, November 23). Pengertian Mencatat berdasarkan ilmu pendidikan. (B. P. Dewi, Interviewer)

Deporter, B., Reardon, M., \& Singer-Nourie, S. (1999). Quantum Teaching (Membpraktikkan Quantum Learning di RuangRuang Kelas). Boston: Allyn and Bacon .
Ghufron, M. N., \& Rini Risnawita, S. (2012). Gaya Belajar (Kajian Teoritik). Yogyakarta: Pustaka Pelajar.

Kertiasih, P. N. (2012, November 28). Pengertian Mencatat berdasarkan Pedagogik. (B. P. Dewi, Interviewer)

Kompas. (2012, Oktober 28). Mind Map sebagai Teknik Mencatat. 26 November 1991, pp. 137-139.

Kountur, R. (2004). Metode Penelitian (untuk penulisan skripsi dan tesis). Jakarta Pusat: CV. Teruna Grafica (PPM).

Nurdaliana, Dimpudus, A., \& Sumarno. (2011, Januari 31). Peningkatan Hasil Belajar Matematika Siswa SMPN 21 Samarinda Melalui Tulis Susun. skripsi tidak diterbitkan. Retrieved from http:/isjd.pdii.lipi.go.id/admin/jurnal/81076271.pdf

Nurgiyantoro, B., Gunawan, \& Marzuki. (2009). Statistik Terapan untuk Penelitian Ilmu-Ilmu Sosial. Yogyakarta: Gadjah Mada University Press.

Olivia, F. (2009). Membantu Anak Punya Ingatan Super. Jakarta: PT. Gramedia.

Perjuangan, I. (2012, November 24). Pengertian Mencatat berdasarkan Psikologi. (B. P. Dewi, Interviewer)

Porter, B. D., \& Hernacki, M. (2002). Quantum Learning (Membiasakan Belajar Nyaman dan Menyenangkan). Bandung: Kaifa.

Priyatno, D. (2012). Belajar Cepat Olah Data Statistik dengan SPSS. Yogyakarta: C.V. Andi Offset.

Purba, G. O. (2009). Gambaran Penerapan Quantum Learning pada Mahasiswa PsikologiUniversitas Sumatera Utara. skripsi tidak diterbitkan, 33.

Purwani, P. (2012, November 21). Pengertian Mencatat berdasarkan bidang bahasa Indonesia. (B. P. Dewi, Interviewer)

Rahajeng, U. W. (2012, November 24). Pengertian mencatat berdasarkan psikologi. (B. P. Dewi, Interviewer)

rahasia kebiasaan daya ingat kuat para jenius. (n.d.). Retrieved januari 22, 2013, from http://www.anehdidunia.com/2012/03/rahasia-kebiasaandaya-ingat-kuat-para.html

Rostikawati, R. T. (2009, 10 02). Mind Mapping. Metode Quantum Learning. article. Retrieved from http://etalaseilmu.wordpress.com/2009/10/02

Salirawati, D. (2008). Pengaruh kemampuan Mendengarkan dan Mencatat terhadap Prestasi Belajar Kimia. Jurnal Pendidikan Tahun XXXVIII. No 1 Mei 2008.

Santrock, John W. (2004). Educational Psychology, 2nd Edition. New York: McGraw-Hill Company, Inc. (2007). Remaja. Jakarta: Erlangga.

Slavin, R. E. (2009). Educational Psychology Theory and Practice. New Jersey: Kevin M. Davis.

Sugiyono. (2005). Statistika untuk Penelitian. Bandung: CV. Alfabeta.

Sukandarrumidi. (2004). Metodelogi Penelitian Petunjuk Praktis untuk Peneliti Pemula. Cetakan kedua. Yogyakarta: Gadjah Mada Universitty Press.

Suparwa, I. N. (2012, November 21). Pengertian mencatat berdasarkan linguistik. (B. P. Dewi, Interviewer)

Suroso. (2004). SMART BRAIN (Metode Menghafal Cepat dan Meningkatkan Ketajaman Memori). SIC.

Umar, H. (2002). Metode Riset Komunikasi Organisasi (cetakan pertama) . Jakarta: PT. Gramedia, Pustaka Utama. 


\section{A. G. B. P. DEWI DAN K. R. INDRAWATI}

Ummah, K. (2012, november 20). articles home schooling. Retrieved from http://www.khoiruummah.sch.id

Uno, H. B. (2010). Orientasi baru dalam Psikologi Pembelajaran. Jakarta: PT. Bumi Aksara.

Usman, H. (2006). Pengantar Statistika Edisi kedua. Sinar . Grafika Offset.

Weisberg, S. (2005). Applied Linear Regression, third edition. New York: Wiley. Web reference. www.stat.umn.edu/alr

Wulandari, T. (2009). Perbedaan Kemampuan Mengingat Ditinjau dari Gaya Belajar. Skripsi tidak diterbitkan, 5.

Zainuddin. (2011). Kematangan Psikologis dalam membangkitkan minat belajar siswa. skripsi tidak diterbitkan (Universitas Tanjung Pura Pontianak). 